\title{
PROF. DR. ANDRIES WILLEM LATEGAN
}

Hierdie Curriculum Vitae sou voorgelees gewees het met die inougurele rede van wyle prof. dr. A. W. Lategan met die aanvaarding van 'n ereprofessoraat aan die P.U. vir C.H.O. op 29 Oktober 1965. Prof. Lategan is op 23 Oktober 1965 oorlede. Sy inougurele rede verskyn as 'n bylaag in hierdie uitgawe.

Andries Willem Lategan is gebore op 30 Desember 1915 te Burgersdorp K.P. waar hy ook in 1933 in die eersteklas matrikuleer. Hy sit daarna sy studies voort aan die Universiteit van Pretoria (1934 tot 1938) waar hy die grade B.Sc. en M.Sc. behaal, laasgenoemde in Industriële en Analitiese Chemie.

Vir die volgende ses jaar, d.w.s. tot 1944 , is hy werksaam by National Chemical Products, Germiston, waar hy vorder tot hoofskeikundige. Gedurende die tyd behaal hy die D.Sc.graad, ook aan die Universiteit van Pretoria, met 'n proefskrif oor katalitiese dehidrogenasie van etielalkohol na asetoon. Publikasie van dic proefskrif is verbied deur die maatreëls op oorlogsgeheime.

In 1945 verhuis hy na Kaapstad waar hy by die Federale Nywerhede Groep in diens tree; hier vorder hy tot hoofnavorsingsskeikundige en behaal terselfdertyd aan die Universiteit van Kaapstad die Ph.D.-graad op grond van 'n proefskrif oor „Aspects of the Chemistry and Technologv of Soup-film Shark Liver Oil". Dié werk het ho-e-vakuum distillasie van vislewertraan ingesluit met die oog op die nasporing van die voorkoms en sintese van vitamiene $A$ in die lewens van sekere visse.

$\mathrm{Na}$ voltooiing van die Ph.D.-graad en navorsing op visolies, het $\mathrm{dr}$. Lategan opgetree as nywerheidskonsultant vir die Federale Groep en het meegehelp om etlike nywerhede te vestig.

$\mathrm{Na}$ enkele jare van diens by voorgenoemde maatskappyegroep word hy gevra om die Stigtingsdirekteur van die Nasionale Voedingsinstituut te word. Hy het hierdie Instituut gevestig, en selfs die geboue daarvoor help ontwerp. In 1956 word hy genader om direkteur van die Suid-Afrikaanse Buro vir Standaarde te word - 'n pos wat hy tot sy dood beklee het.

Daar het verskeie navorsingspublikasies van $\mathrm{dr}$. Lategan 
verskyn in die Journal of the Society of Chemical Industry - 'n Britse tydskrif - en in die Journal of the S.A. Chemical Institute o.a. ' $n$ viertal oor die samestelling en tegnologie van lewertraanolies en die vervaardiging van vitamien A-konsentrate.

Verskeie van sy navorsingsresultate wat as adviese aan die maatskappye vir wie hy gewerk het, gedien het is nooit gepubliseer nie. Hy het ook 'n groot aantal verslae van wetenskaplike en tegnies-tegnologiese aard vir dié maatskappye saamgestel.

Dr. Lategan het op verskeie openbare, wetenskaplike en ander liggame en organisasies gedien. Hy was o.m.:

i. Voorsitter van die Motoradvieskomitee van die Minister van Ekonomiese Sake.

ii. Lid van die Wetenskaplike Adviesraad van die Eerste Minister.

iii. Lid van die Verdedigingshulpbronneraad.

iv. Lid van die Ykraad.

v. Lid van die Sentrale Raad vir Mediese Skemas.

vi. Lid van die Raad van die Pretoriase Tegniese Kollege.

vii. Lid van die Raad van dic Universiteit van Pretoria.

viii. President van die Konvokasie van die Universiteit van Pretoria.

ix. Lid en jarelange Raadslid van die Suid-Afrikaanse Chemiese Instituut.

x. Lid van die Suid-Afrikaanse Akademie vir Wetenskap en Kuns. In die verband is hy o.a. stigterslid en later ook voorsitter van die Afdeling Chemie.

Beide dus wat sy akademiese opleiding aanbetref sowel as sy belangstelling vir die grondbeginsels en die toepassing in die praktyk, het dr. Lategan duidelik getoon dat hy in hart en siel 'n Industriële Chemikus was.

Dit was dus bloot natuurlik dat die P.U. vir C.H.O. hom sou nader toe die Universiteit etlike jare gelede besluit het om sy vlerke in die rigting uit te sprei. Sonder aarseling het dr. Lategan sy hulp en raad aangebied en het hy 'n leeue-aandeel gehad met die stigting van die departement Industriële Chemie aan ons Universiteit deur die advies, leiding en aanmoediging wat hy ons gedurig gegee het. $\mathrm{Hy}$ het op 'n keer die fakulteitsraad van Natuurwetenskappe oor die aangeleentheid toegespreek en was ook lid van die breë Advieskomitee wat ons Universiteit in verband met die saak voorgelig het. 
Dit was dus 'n natuurlike ontwikkeling dat dr. Lategan die eerste Ere-Professor van dié Departement sou word: daardeur wou ons aan 'n "groot man" ons dank en waardering betuig. Hy was ook lid van die Raad van Beskermhere van die P.U. vir C.H.O.

Alhoewel hy 18 maande lank ernstig siek was, het dr. Lategan tot die dag voor sy dood gewerk en daar kan letterlik gesê word dat hy in die tuig gesterf het, soos hy dit sou wou gehad het.

Dr. Lategan was 'n menslike mens, 'n man met 'n opgewekte persoonlikheid, aansteeklike glimlag en 'n innemende geaardheid, 'n man wat onder die hoës hoog geag is en deur die jongeres met agting bejeën is omdat hy hulle nooit snobisties behandel het nie.

Boweal was hy 'n innige gelowige wat jou gedurig onder die indruk gebring het dat hy met sy God wandel soos tewens sy hele lewe getuig het.

Dr. Lategan was getroud met mej. Lina Strydom. Hulle het drie dogters en 'n seun en twee dogters is oud-studente van die P.U. vir C.H.O.

Ons aan die P.U. vir C.H.O. het in dr. Lategan 'n goeie vriend gehad en ons bring in dankbare herinnering wat hy vir ons gedoen het.

Aan sy familie betuig ons ons innige meegevoel en bid hulle toe die vertroosting van die Heilige Gees.

P.U. vir C.H.O.

S. P. Ligthelm. 